\title{
OL, politik og sport - En introduktion
}

På trods af talrige forsøg på at frasige sporten politiske dimensioner - eller ansvar - viser artiklerne i dette første nummer af Forum for Idræt, at uanset hvordan man vender og drejer det så er idræt og sport en del af det omgivende samfunds debat og bevidsthed - endog ofte med storpolitiske konsekvenser. Udover, at OL i sig selv er en stor begivenhed, så blev dets politiske dimensioner i særdeleshed aktualiseret med legenes afholdelse i Kina. Spørgsmålet om menneskerettigheder, pressefrihed, internationale magtpolers forskubbelse, Tibet og Taiwan, terrortruslen men også Kronprinsens IOC ${ }^{1}$-kandidatur og dansk eliteidræts succes prægede den hjemlige debat før, under og efter Beijing. Derfor fandt redaktionen det naturligt at lave et tema-nummer om verdens vel nok største sportsbegivenhed, da denne giver anledning til at drøfte en række spørgsmål om forholdet mellem sport og politik.

Overordnet set kan nærværende arbejde på denne baggrund ses, som et punktvis nedslag i de mange drøftelser og storpolitiske spil, der har kørt såvel nationalt som internationalt $\mathrm{i}$ forbindelse med OL i Kina og IOC's session og kongres, der blev afholdt i Danmark i oktober 2009. Tema-nummeret er ganske vist analytisk fokuseret på begivenheder, der allerede har fundet sted, men drøftelserne om betydningen af idræt-

1. Den internationale olympiske komite.
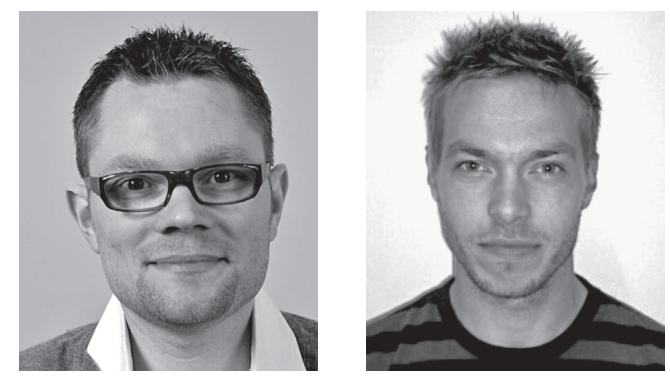

AF RASMUS

K. STORM (tv.)

OG

PETER JUL

JACOBSEN (th.)

tens politiske elementer forstummer ikke, da OL i Kina og IOC-arrangementet i Danmark peger frem med de kommende lege og nye spørgsmål.

Tværtimod er der efter vores opfattelse meget der tyder på, at sportens politiske dimensioner - som aldrig før - stikker sit ansigt frem, uanset om dets tilstedeværelse vækker ubehag eller ej.

\section{OL I BEIJING - MARKEDSKRAFTERNES SEJR OVER MORALEN!}

Første artikel illustrerer på bedste vis dette i form af en analyse af vestens håndtering af $\mathrm{Ki}$ nas nye økonomiske magtposition. I »OL i Beijing - markedskræfternes sejr over moralen « viser Jørn Hansen således, hvordan Europa og USA's komplekse og ambivalente forhold til Kinas udvikling og magt, finder konkret udtryk. 
Det centrale anknytningspunkt i Hansens artikel er herunder spørgsmålet om, hvordan man forklare, at verdens førende statsledere trods deres udtalte kritik af det kinesiske styre, alligevel endte med at bakke op om de olympiske lege? Svaret er i sin korte form, at vestens økonomiske interesser på det kinesiske marked samt Kinas stigende internationale økonomiske betydning i sidste ende sætter de moralske udfald mod eksempelvis menneskerettighedsproblematikken samt fraværet af reelle demokratiske reformer til vægs. De økonomiske hensyn og angsten for at miste markedsandele synes at vinde over politikken, er Hansens pointe kort og godt.

Problemerne med dobbeltmoral fra omverdenen og menneskerettighederne internt til trods, beskriver Hansen også mange positive sider af Kinas udvikling. Ifølge Hansen har det kinesiske styre blandt andet løftet en halv milliard kinesere ud af fattigdom, en proces der ikke er set tidligere i verdenshistorien. Trods uheldige eksperimenter under Mao, er det altså overordnet et positivt billede, der tegnes. Ifølge mange Kina-kendere er der ifølge Hansen udbredt enighed om, at udviklingen går i den rigtige retning, og at den bevidstløse kritik i sin mest ekstreme form kan tolkes som utålelig bedreviden, der ikke tager Kinas egenart - kulturelt, politisk og historisk - alvorligt. Dobbeltmoralen og den vestlige bedreviden kan således trænge til en omgang selvrefleksion.

\section{DE POLITISKE SPIL OMKRING OL I BEIJING}

Nogenlunde samme opfattelse af omverdenens kritik af Kina anlægger Clemens Stubbe Østergaard i dennes analyse af de politiske spil omkring OL i Beijing. Med udgangspunkt i blandt andet "framing-teori " argumenterer Østergaard således, at selvom der utvivlsomt er problemer med det Kinesiske styres håndtering af eksem- pelvis menneskerettighederne, så blokerer den særlige "framing" af Kina i verdenspressen for en rimelig afdækning af styrets problemer i den bredere offentlighed.

Ifølge Østergaard er den optik som det kinesiske styre ses igennem konnoteret af repression og politisk undertrykkelse på en måde, der præger stort set alle historier om landet. Dermed promoveres en særlig negativ problemdefinition, en tilsvarende tolkning med en efterfølgende moralsk evaluering og opkoblede løsningsforslag overfor den vestlige offentlighed, hvilket imidlertid har den utilsigtede konsekvens, at det kinesiske styre blot trækker sig længere væk fra dialog.

Konkret gav den ensidige framing af Kina sig blandt andet udslag i en meget gennemgående misforståelse om Kinas løfter forud for legene. På trods af, at Kina rent faktisk ikke havde afgivet et positiv løfte om at forbedre menneskerettighederne, så domineredes den mediemæssige dagsorden før og under legene af en gennemgående historie om, at Kina ikke havde opfyldt det løfte nationen rent faktisk ikke havde givet. Systemet havde lovet, at den internationale presse kunne rapportere frit fra legene. Ikke andet.

Selvom IOC undervejs i forløbet forsøgte at korrigere opfattelsen af, at der var blevet givet løfter om mere vidtrækkende menneskerettighedstiltag blev dette aldrig taget op i de store dominerende medier. Framingen af Kina som repressionssystem blev således fastholdt ukritisk. Da en meget central pille af det nuværende styres identitet samtidig hviler på at forene nationen, forhindre udenlandske magter $\mathrm{i}$ at dele den, og genvinde dens værdighed, betyder dette ifølge Stubbe Østergaard, at en række centrale kinesiske spørgsmål - eksempelvis om Tibet, Taiwan og Xinjiang - er yderst ømfindige.

Nationen har ganske enkelt en meget lav tær- 
skel for udenlandsk kritik og nul-tolerance for tab af ansigt $\mathrm{i}$ henseende hertil. Skal man i dialog må man derfor træde varsomt, og her hjælper det ikke at formidle vestlig kritik i en ramme, der farver nations udvikling $i$ et efter kinesernes opfattelse uretfærdigt lys. Dette er vel nok en af de vigtigste pointer, der kan uddrages af Stubbe Østergaards artikel.

\section{DANMARKS POSITION I DET INTERNATIONALE ELITESPORTSKAPLøB - POST BEIJING}

OL i Kina har imidlertid ikke kun afstedkommet debat om håndtering af menneskerettigheder i værtsnationen. På et noget mere jordnært og hjemligt niveau har den danske deltagelse $\mathrm{i}$ de olympiske lege afstedkommet en idrætspolitisk debat om dansk eliteidræts niveau og ambitionerne for fremtiden. Selvom medaljehøsten ved legene levede op til målet, har Team Danmark samt en række fremtrædende eliteudøvere efterfølgende klaget deres sag, og forlangt flere penge til elitearbejdet, da den danske konkurrenceevne synes presset som følge af store internationale investeringer i stadig flere lande.

Men, hvad er den danske position i det internationale elitesportskapløb reelt? Og, hvilke konkrete problemstillinger står dansk eliteidræt overfor i forhold til at vinde flere internationale medaljer? Dette er hovedspørgsmålet i Rasmus K. Storms artikel: "Danmarks position i det internationale elitesportskapløb - post Beijing«. Overordnet set konkluderer Storm, at den danske konkurrenceevne ganske rigtigt er presset. Ifølge Storm er dette afstedkommet af det forhold, at den internationale konkurrence har været stigende kombineret med en stagnation i Team Danmarks tilførsel af ressourcer. Det naturlige spørgsmål, der rejser sig er derfor, skal der sendes flere penge til de danske atleter fra statskassen?
Først og fremmest er dette ifølge Storm et politisk spørgsmål. Der er ikke nogen nødvendighed i, at Danmark som nation skal satse på eliteidræt eller tage del i medaljekapløbet. I det større politiske spil er satsning på elitesport eller ej et spørgsmål om prioritering af samfundsøkonomiske ressourcer. Altså politik, der uundgåeligt rækker videre end sportens egne områder. Storm peger derfor på, at danske politikere - når alt kommer til alt - må drøfte sig frem til et gældende ambitionsniveau, ligesom de bør vurdere om dette skal indbefatte allokering af midler fra andre samfundsområder. Hvis ikke må man følgelig sætte målsætningerne derefter. Derudover kan Team Danmark selv gøre noget ved at forbedre de områder af elitemodellen der peges på i artiklen.

\section{DANSK IDRAT OG DEN NAZISTISKE UDFORDRING I 1930'ERNE}

Hvor de tre første artikler i dette temanummer har vist de politiske aspekter af sporten, tager den sidste videnskabelige artikel i dette temanummer sit helt eksplicitte udgangspunkt $i$ at demonstrere det uadskillelige forhold mellem sport og politik. Udgangspunktet er ikke OL i Kina i 2008 men derimod en analyse af de politiske konsekvenser af samkvemmet med den tyske sport der kulminerede i de olympiske lege i Berlin 1936.

I artiklen "Dansk idræt og den nazistiske udfordring i 1930'erne« tager Hans Bonde således fat $\mathrm{i}$ et stykke dansk idrætshistorie, hvor forholdet til den truende fremmedmagt blev formet $\mathrm{i}$ lyset af anden verdenskrig gennem brug af sport. Således anfører Bonde, at den danske parole om, at sport og politik ikke har noget med hinanden at gøre netop gav tyskerne adgang til en uhæmmet politisering af sporten før og un- 
der besættelsen. Propagandaeffekten for det tyske regime var derfor enorm.

De Olympiske Lege i 1936 i Berlin var herunder ifølge Bonde den enkeltbegivenhed, der bragte danskerne tættest på nazisternes satsning på storslået arkitektur, organisation og orden og forsøget på at skabe stærke fællesoplevelser gennem imponerende optrin af store menneskemasser, men allerede inden havde dansk idræt bevæget sig mere og mere fra individuel til national selvhævdelse, fra lyst- til elitesport, fra amatørisme til professionalisme og fra at dyrke idræt og se op til en demokratisk nation som England til at spille mod den nye dynamiske tyske sportsnation.

Gevinsten ved dette uskyldstab var, at den danske sport oplevede et gigantisk præstationsløft og fik mulighed for at bade sig i national stolthed ikke mindst gennem den entusiastiske deltagelse i de olympiske lege i Berlin.

Således sluttede mellemkrigstidens danske idrætshistorie med et stadigt mere intenst og politiseret samkvem med den stærke nabo mod syd kulminerende med, at Danmark i modsætning til Sverige og Norge fortsatte idrætssamkvemmet med tyskerne i perioden fra tyskerne startede Anden Verdenskrig i september 1939 til besættelsen 9. april 1940. Men inden da havde idrætten i Danmark allerede for længst tabt sin uskyld.

\section{MODERNE SLAVEHANDEL}

Som et nyt initiativ i tidsskriftet vil fremtidige udgaver af Forum for Idræt indeholde mindst ét bidrag skrevet af studerende ved et af landets universiteter. Formålet er, at inspirere studerende til at publicere deres respektive arbejder, der ofte indeholder ny interessant viden, men som kan have svært ved at finde vej til offentligheden.
Selvom studenterartiklen i dette nummer ikke handler om de Olympiske Lege så har emnet endog kraftige politiske dimensioner. I artiklen "Moderne slavehandel« viser Jacob Ebsen Madsen således, at moderne professionel fodbold har en skyggeside, der burde kalde på politisk intervention.

I takt med kommercialiseringen af især europæisk fodbold, er der nemlig opstået et helt nyt og delvist ureguleret marked for (billige) afrikanske spillere. På dette marked agerer agenter med tvivlsomme motiver, der tager sig godt betalt med penge som familierne ofte må låne i håb om, at deres sønner kan opnå en lys økonomisk fremtid. Når spillerne kommer til Europa risikerer de imidlertid at blive efterladt uden kontakt til nogen konkret klub, og uden anden mulighed end at forsøge sig med kriminalitet og/eller prostitution.

På trods af, at FIFA i 1995 indførte et licensbaseret agentsystem har organiseringen med at lade de nationale forbund håndhæve reglerne vist sig aldeles utilstrækkelige. Der er ifølge Madsen meget stor forskel på, hvordan de enkelte nationale forbund agerer og om de overhovedet gør noget for at forhindre de illegale agenter $\mathrm{i}$ at operere.

Resultatet af udnyttelsen af unge talenter har - udover de rent individbaserede - også negative konsekvenser for afrikansk fodbold: dårlig økonomi i klubberne og ligaer med færre tilskuere og en dalende interesse fra medierne. Alt sammen forhold, som er med til at forøge afrikanske talenters interesse i at komme til Europa.

Ifølge Madsen er der dermed er der tale om en selvforstærkende ond cirkel. Indtil smuthullerne bliver lukket, vil Afrika blive ved at miste deres fodboldtalenter uden kompensation. Med de store summer agenter og klubber kan tjene ved handel af spillere, er det ikke nok at lade 
etik og moral være styrende. "Der skal også love og regler til«, som Madsen anfører slutteligt i sin artikel. Ikke bare sportens politiske dimensioner, men også politikkens relation til sporten belyses således i denne artikel.

\section{CHAMPIONS LEAGUE-GENERATIONENS DOMINE- RENDE ROLLE}

Marco de los Reyes bekymrer sig over udviklingen i mediedækningen af sport. Der står fodbold på alt, og det går udover dækningen af andre sportsgrene samt den generelle interesse for disse. Gennem de seneste årtier er danskerne blevet fodret med succes i de store sportsgrene, især international fodbold, og derfor er danskerne efterhånden mere ligeglade med mindre sportsgrene uanset deres internationale resultater, skriver han i kronikken: "Champions League-generationens dominerende rolle«. De to kajakroere, der vandt OL-sølv i Beijing, kunne givetvis bevæge sig rundt i centrum af København i flere timer, uden nogen kunne genkende dem. Og hvad er nu navnene på de to sejlere, der vandt OL-guld?«, spørger de los Reyes.

Udviklingen er ifølge de los Reyes blandt andet dikteret af udviklingen i mediebilledet, hvor især liberaliseringen og ændringen af Danmarks Radios monopol med TV2's lancering fik kanalerne til at gå efter mest populære sportsgrene. Før monopolbruddet var visningen af også smalle sportsgrene langt større, men det blev der lavet om på, da TV2 med anderledes indstilling til tv-sport gik i luften 1 . oktober for lidt over 20 år siden.

Siden er der desuden kommet flere tv-kanaler til, og sport og især fodbold er blevet et stærkt middel i kampen om seerne. Viasat var fra start på banen, da Champions League-fodbolden så dagens lys i sæsonen 1992/1993, og siden har man især på Viasats kanaler - TV3 og 3+ er et par af dem - kunnet se et hav af fodboldkampe på højeste internationale niveau. Dette har ifølge de los Reyes skabt „Champions League-generationen«, der er vant til et helt specielt sendeudbud uden den store variation, og da segmentet er voksende, er der ikke meget som tyder på, at udviklingen vil ændre sig i fremtiden. Bredere set er det også gældende, at de fleste medier inden for sportsjournalistikken satser meget mere på det velkendte stof, end tilfældet er inden for kulturjournalistikken, erhvervsjournalistikken og den politiske journalistik. Dette sker fordi sportsjournalistikken på tv og i stigende grad på nettet og i aviserne er en del af underholdningsbranchen.

Men, hvad er så problemet med det? Spørgsmålet er måske nok velkendt, men svaret kan afhængigt af holdningen variere. Ifølge de los Reyes er konsekvensen for de smalle sportsgrene, at disse primært dækkes i forbindelse med OL men, at de derudover må leve en afsondret tilværelse. Problemet er selvsagt nedgang i interesse, der i sidste ende kan resultere $i$, at der er færre som vil dyrke de berørte sportsgrene samt fraværd af legitimitet i forhold til en bredere befolkningsmæssig opbakning til støtte - eksempelvis gennem Team Danmark.

På bredere plan betyder det ensidige fokus tillige en nedgang i sportsjournalistikkens evne til at formidle idrætspolitiske problemstillinger, og i den forstand bevæger det idrætspolitiske system og sportsjournalistikken sig bort fra hinanden. Ifølge de los Reyes kan man frygte, at den afstand kun bliver større når Champions League-generationen bliver større. Om 20 år vil antallet af unge flasket op med fodbold ikke interessere sig for meget andet end det velkendte underholdningsprodukt. 


\section{FRA BERLIN TIL BEIJING. ET ESSAY OM SPORT OG POLITIK}

Hans Bonde slutter temaet om OL, politik og sport af med et essay, der gennem en række konkrete historiske eksempler - fra Berlin til Beijing - viser, hvorledes sport og politik ofte er tæt vævet sammen.

Blandt andet leverer Bonde en skarp kritik af det kinesiske styres anvendelse af OL som propaganda maskine med politiske motiver. Bondes hovedpointer er, at trods Kinas ubestridelige fremskridt må omverdenen ikke lukke øjnene for, at regimet stadig bygger på det gamle kommunistpartis magtmekanismer - blot i moderniseret form. Således - er det Bondes argument er Kina ganske vist moderne når det gælder økonomisk vækst og teknologiske fremskridt, men ikke i forhold til udviklingen af et dialogisk og åbent civilsamfund, der kan kritisere og skabe debat om det kinesiske samfunds udviklingsprocesser.

Udover denne generelle kritik kommentarer Bonde i essayet også spørgsmålet om Kronprinsens kandidatur til den Olympiske Komite (IOC), der var heftigt debatteret op til legene i Beijing. Debatten er ikke blevet mindre aktuel efter, at Kronprinsen blev valgt ind i forbindelse med IOC-kongressen i Danmark i oktober 2009.

I forhold til Kina, men også fremtidige spørgsmål i forhold til andre værtsnationer eller problematikker, der opstår i forbindelse med afholdelse af legene, er det vigtigt at idrætslederne og kronprinsen er bevidste om de politiske implikationer, som også er en del af den sportslige aktivitet, så atleter, trænere og ledere kan undgå at blive brikker i et politisk spil. Ifølge Bonde er det klart, at DIF får utrolig god branding ud af kronprinsens kandidatur, men mindre soleklart, om kongehuset ikke mister noget af sin integritet ved at stikke hånden ind i den idrætspolitiske hvepserede.

Hertil kommer, at den danske kronprins har sværget en olympisk ed om absolut loyalitet overfor IOC. Derved risikerer han ifølge Bonde at komme i modstrid med den danske regering, hvilket i fald vil være til skade for monarkiet. Som Bonde ganske rigtigt peger på har der i hvert fald to gange før været fundamental uenighed mellem IOC og den danske regering.

Den første gang var i 1998/99, da den danske regering pressede på for oprettelsen af et uafhængigt dopingagentur (WADA) - mod IOCs vilje. Den anden gang var fra 2000 - 2004, da IOC iværksatte et pres for at indføje en artikel i EU's traktatgrundlag, der skulle undtage sporten fra reglerne om arbejdskraftens frie bevægelighed - en særregel den danske regering var meget imod.

At sporten således har en række politiske interesser, og at sport og politik altså er svært adskillige størrelser skulle dermed være illustreret endnu en gang. Og problemerne bliver nok ikke mindre i fremtiden.

Ifølge Bonde er frasen om sportens og politikkens adskilthed derfor blot et forunderligt tomt tegn, som kan bruges til at give en hvilken som helst idrætspolitisk handling et ædelt og neutralt skær. Man gør derfor klogt i at spidse ørerne, når en idrætsleder eller politiker hævder, at sporten er hævet over politikken, for et sådant udsagn er i reglen et skalkeskjul for en stærk politisering af sporten, slutter Bonde. 